\title{
Sustainable tourism development and handicrafts in the developing world
}

\author{
H. Zargham \\ Allameh Tabatabai University, Iran
}

\begin{abstract}
Since World War II, mass tourism has been one of the key industries promoted by governments all over the world. In modern times, many developments such as economic globalization have given sustainable tourism a sizeable push forward. Although tourism currently plays a relatively small role in the economy of some developing countries such as Iran, it is projected today as an engine of economic growth and an instrument for eliminating poverty, curbing unemployment problems, opening up new fields of activity, and enhancing the quality of life particularly among the most vulnerable sectors of society. New opportunities are being tapped to extend cultural, adventurous, rural, health, and medical tourism. With the number of foreign tourists on the rise and also domestic tourism gaining popularity, public and private sector bodies are actively involved in promoting tourism in almost all developing states. Furthermore, the international and regional dimensions of tourism are also receiving due recognition and, accordingly, tourism has been instrumental in softening the relations among nations towards peace.

Seeking primarily an economic and sociological analysis of indigenous handicrafts while not overlooking these products in terms of their artistic and anthropological value, this paper will uncover the complexity involved in the promotion of cultural assets of the tourism industry. It aims to explore new strategies that would protect the sustainability of people's livelihoods, identity, and also increase knowledge for encouraging, supporting, and developing tourism and crafts promotion. The specific objectives of this paper include identifying the handicrafts that affect the sustainable development of respective tourism industries, evaluating the sufficiency of handicrafts in attaining sustainable tourism development; and suggesting ways of improving handicrafts to guarantee further sustainable development of tourism.
\end{abstract}

Keywords: mass tourism, sustainable tourism, handicrafts, development. 


\section{Mass tourism versus sustainable tourism}

In most developed countries of the world, the general public is constantly fed with contradictory pictures of Iran through the various media; from the ordinary news to tourism guide books and journals. At one extreme stands the association with fundamentalist terrorism and/or the presence of a resilient populace, scarcity of basic commodities and prevalence of communicable diseases. At the other, however, there are also some sectors of the tourism industry portraying friendly peoples, scenic beauty, pristine environments, and historical and cultural diversity. On the ground, tourism (whether domestic or international) provides the opportunity for cultural exchange and fosters understanding between nations. Moreover, it plays a key part in the development of both suburban and rural areas and can play an important role in cultivating and promoting culture and heritage. However, since tourism is not a unitary phenomenon, its effects vary according to its purpose and activities. Therefore, it is necessary to categorize the types of tourism which are promoted in different communities.

Today the tourism industry is developing conventional mass tourism towards new forms which are inclined to satisfy growing needs for authenticity, participation, and activity as a counter-reaction to arranged, clustered, and predictable mass tourism or traditional tourism [1]. This notion generally refers to the big conglomerates or tourist resorts in the world where tourist companies are property of big multinational corporations, where one expects the same type of service and facilities whether in Tehran or in New York, and where there is little interaction with local communities [2].

On the other hand, there is also the emergence of alternative or sustainable tourism, a concept defined away from mass tourism. Under the sustainable tourism concept, one can encounter a series of classifications and categories of tourism. What characterizes the concept of sustainable is the existence of small or medium-size companies created by families or friends where there is the possibility of more contact with communities and where there is generally a sense of respect for the environment. This concept is often utilized by government institutions and academics; indeed very rarely would a traveller referring to an information centre inquire for places or activities affiliated with sustainable tourism. Ecotourism, rural tourism and cultural tourism are only some of the branches under the concept of new tourism and they all develop on their specific criticisms against mass tourism. Statistically of course, it is still mass tourism that leads the league but tourism authorities lay a strong belief in the future potentials of sustainable tourism.

There are three concepts that are fundamental to the analysis of new tourism: globalization, sustainability, and development [1]. Furthermore, these three concepts are rapidly becoming interchangeable and prevalent. For many tourism destinations, the reward phase of development is characterized by a long and intense growth in infrastructure, superstructure, and facilities which, sooner or later, seriously bear impact on the environment thus creating a critical situation.

Cultural tourism is one of the new and strongly progressing modes of sustainable tourism. It is based on the search for, and participation in, new and 
deep cultural experiences. Cultural tourism offers novel opportunities for the economic restoration of historical sites but tourismification could jeopardize these cultural resources through its regularity and frequency. The development of cultural tourism in historical destinations initiates an irreversible process of change both in forms and functions and pre-cognizance of the consequences is indubitably of paramount importance.

For residents of a region, cultural tourism is an activity prompting job creation, income generation, and improvement of the living conditions of the grass roots. Cultural tourism endorses cultural aspects that are of interest to the visitor and can be marketed as such, including the customs and traditions of people, their heritage, history, and way of life. Cultural tourism is thence a form of job providing in which the locals take direct part through its design and organization [3]. Cultural Tourism is an opportunity for these communities to show tourists all aspects of their life from handicrafts and folk culture to lifestyle.

What is actually taking effect is that the environment for tourism is changing and, in order to grow and prosper, the tourism industry will need to be more flexible and responsive towards challenges. Involvement of the local people is one of the missing ingredients undermining the success of many tourist destinations. To this end, associating the private sector is one of the keys to unlocking the potential of local communities in the tourism industry. There are a number of ways in which the public and private sectors could support community involvement in tourism; the most practical policy for involvement of the local people is promoting production of handicrafts.

\section{Handicrafts}

Handicrafts depict a cultural trait of a specific region/time and are defined as products made without the use of tool. They are simple implements or implements operated directly by the craftsman/woman, by hand or foot, having traditional or artistic features driven from the geographical cultural peculiarities of craftsmen/women and generally on a small industry and not on a mass production basis [4].

Handicrafts have been developed from the usage of everyday household items which were decorated and used for ceremonial purposes. Strictly speaking, handicrafts are occupations that involve making usable or decorative products by hand. Before the Industrial Revolution, all such products were handmade, often in the home. The age of the machine nearly did away with the traditional crafts by fostering mass production [5]. Handicrafts incorporate a wide variety of the uses of natural woods, wool fibers, stones, copper, etc. Ceramic items, for instance, range from everyday common vessels and plates to fine ceramic pieces that became heirlooms passed down from generation to generation. The diversity in Iranian textile forms is astounding and is yet another representation of the country's rich cultural heritage. The symbolism of Iran's various ethnic groups is evident in the variety of carpets. Color, shapes, and their arrangements all have specific meanings. Wooden carving traditions and skills can also be found 
throughout the land. Even amongst wooden carvings within one ethnic group, differences in design, style, and subject matter are easily evidenced after some study. And as if the above are not enough, stone carving traditions and painting as an art form are also common-place in Iran dating back to over 1400 years ago.

Iran has always been a storehouse of intellectual and cultural wisdom and its diversity, cultural richness, and multifarious ways of living place it in a unique position of being able to offer many culturally distinctive handicrafts to the entire world. Whatever the tourists' taste and pleasures, they would soon enjoy the exploration of the various Iranian art forms of handicrafts and enjoy collecting a few for themselves.

Consequently, handicrafts will be a catalyst of the national tourism direction to position Iran as a cultural tourism destination, and a champion for development of a strong and vibrant tourism sector which contributes to sustainable economic growth, job creation, poverty alleviation, and protection of the natural and cultural heritage.

Handicrafts are a catalyst to promote tourism as one of the key economic sectors, contributing effectively to the country's GDP and encouraging private sector involvement [6]. Handicrafts continue to play an important role in the economies of all developing countries; they not only constitute major manufacturing activities in themselves but are also often the only available means to provide additional employment and raise the level of living for both rural and urban populations [7].

The most dangerous challenge facing the handcrafts sector is the emigration of workers looking for new better jobs that would provide a higher standard of living for their family and preserve their dignity. This would eventually mean that many areas would in the long run loose their culture identity. It is, therefore, imperative that all concerned parties join hands and move together to help those working in the traditional handicrafts sector to face the economic failure that had befallen this profession. To this end, representatives of the religious community, ambassadors, and interested organizations should be invited to meetings where the social, economic, political, and religious impact of the improvement of the tourism sector and consequently handicraft production in the developing world would be demonstrated.

\section{Interaction}

Tourism among developing nations basically manifests itself in the form of cultural tourism and ecotourism. Accordingly, the preparation of a cultural tourism strategy should be chosen to serve as a precedent to all other tourism plans.

The cultural attractions of a country can be dichotomized as hard and soft. The former includes historical and archeological sites, museums, monuments, and places of worship, while the latter consists of works of music, drama, poetry, literature, painting, sculpture, herbal medicines, folklore, and handicrafts. Both categories have to be imaginatively combined in that tourism packages should 
conglomerate one cultural medium with another and incorporate a whole range of lectures, presentations, demonstrations, etc.

Reviewing the literature on tourism illustrates that cultural development as well as national economic development has always been accompanied by handicraft development [8]. Handicrafts and fine arts are not merely cultural products or purely economic products for everyday life but also the specific artworks of social culture indicating the level of economic development, the people's intellectual standard and the degree of humanity within that nation. Handicraft products are among the supporting resources of a destination and supplements of that destination's principle resources.

Moreover, even in modern times when machines readily take over human labor, handicraft products still remain. They exist and develop together with modern techniques and equipment. Consequently, craftsmen/women continue to hold an important position in the development of tourism through their able hands which produce the sophisticated handicraft products [9]. The study of traditional crafts has naturally become an urgent requirement in order to develop the production of commodities and to preserve national and cultural heritage.

In developing sustainable tourism, economic, environmental, cultural, and social values are inseparably interwoven. The quality of life - a major variable for the residents - depends on providing economic opportunities for all, while preserving rural beauty and natural resources and a thriving, diverse community.

Dependency theorists contend that tourism development strips pre-capitalist societies of their economic surplus, causes economic leakage, leaves the least developed nations even more dependent on foreign imports, and ultimately destroys the socio-cultural framework of host countries [10]. Figures, however, show that the more visitors come to a destination, the more customers for handicrafts will emerge; and production and diversification of handicrafts will improve accordingly. In addition, modernization theorists argue that tourism development improves local economies and inhabitants' standard of living.

In any case, handicraft development has to be viewed as an integral part of a society's policy objective for tourism development. Nevertheless, caution has to be expressed that handicraft development cannot be considered as a magic potion for conservation and protection against the harmful influence of tourism on resources exploitation as well as natural, ecological, and social environment; nor can it alone become an economic bonanza to liberate local communities from the pain of poverty.

\section{Strategies to improve handicrafts}

Handicrafts are not only considered as a tourism product based on cultural heritage, but they may also be viewed as cultural assets and thence unending. Craftsmen/women are encouraged to produce handicrafts to be sold as souvenirs of their visit to Iran to tourists and pilgrims. What is more is that handicrafts can also assimilate and support local needs and aspirations.

According to official estimates, nearly four million Iranians are engaged in the handicrafts sector. The industry accounts for 3\% of the GDP, whereas the 
auto industry's share remains between $2.5-3 \%$. In addition to creating jobs, a booming handicrafts sector would dissuade rural people from migrating to industrial zones. In the meantime, officials are of the belief that handicrafts can evolve into a lucrative business for the national economy provided genuine links were established with the tourism sector.

Handicrafts can be one top attraction in the tourism industry given that tribal handicrafts are mostly inspired by the nature, culture, and arts of Iran. They open a window to the nation's past history [11].

The following are a number of suggestions to improve the current state of affairs of handicraft production:

- Focus primarily sustainable tourism development programs on local handicraft businesses.

- Support a marketing campaign for handicrafts and local products and add value by branding a local identity.

- Facilitate and reward responsible tourism planning and management practices for helping the country attract a segment of the tourism market with what is widely considered to be very significant growth potential.

- Encourage local institutions (banks, chambers of commerce, etc.) to support handicrafts' business improvement and enhance marketing for the business support services that currently exist.

- Understand and develop existing handicrafts producer clusters.

- Provide an e-commerce platform for the craftsmen/women.

The artisans of indigenous clusters of handicraft have been marketing their ware directly to local buyers and tourists and also through brokers to export markets, throughout history. The very fact that local artisans need to work with brokers to market their products to the luxurious handicraft boutiques, art galleries, and import stores, portrays their financial output. Implementation of on-line marketing can alleviate the problem of having brokers, and craftsmen/women can gain equitably from their input. Hence the use of e-commerce and ICT capacity-building initiatives that target handicrafts and the organizations that support handicraft businesses should be encouraged.

In essence, handicraft products around the globe are the torchbearers of a community's identity in terms of its local culture, history, and tradition. Needless to say, consolidation of this industry would only extend the economic viability of those communities.

\section{References}

[1] Mowforth M. and Ian Munt (2003), Tourism and Sustainability, development and New Tourism in the Third World, 2nd ed. Routledge.

[2] Moore S.A., Dowling, R.K. (2002), Natural Area Tourism: Ecology, impacts and Management. UK: Channel View publications.

[3] http://www.tourismconcern.org.uk

[4] Oliver-Smith, Anthony (2001), Displacement, Resistance and the Critique of Development. University of Oxford.

[5] Student Encyclopedia of Tourism. 
[6] Denny, C. (2002), Third world seeks justice through fair trade, Guardian Weekly 10-16 January: 20.

[7] Fletcher, J. (1989), Input-output analysis and tourism impact studies, Annals of Tourism Research 16, 4: 514-29.

[8] Derek, Hall and Greg Richards (2000), Tourism and Sustainable Community Development. Routledge.

[9] Jameson, F. (2001), Postmodernism, or the cultural logic of late capitalism. New Left Review 146:53-29.

[10] Khan, Maryam M. Annals of Tourism Research, 1997, 24, 4, Oct, 988991.

[11] Iran Daily. June 20, 2005. Handicrafts as Tourism Magnets.

[12] Los Angeles Times. January 22, 2004, “Low-pay sectors and State Job Growth" 